\title{
O MODELU ADMINISTRACYJNOPRAWNEGO NADZORU NAD PEWNYMI SZCZEGÓLNYMI KATEGORIAMI ZGROMADZEŃ Z PERSPEKTYWY ZASADY DECENTRALIZACJI
}

W roku 1990 przywrócono w Polsce samorząd terytorialny, uznawany za jedną z podstawowych form decentralizacji władzy publicznej. Dokonano tego ustawą z 8.03.1990 r. o samorządzie terytorialnym (obecnie: u.s.g.). Już kilka miesięcy później uchwalono (nieobowiązującą obecnie) ustawę z 5.07.1990 r. - Prawo o zgromadzeniach ${ }^{1}$, prowadzącą do urealnienia w Polsce wolności zgromadzeń. Obie te ustawy stanowiły element szerszych przemian ustrojowych, zapoczątkowanych w 1989 r. Reaktywowanemu samorządowi terytorialnemu powierzono nadzór (zarówno uprzedni, jak i bieżący) nad zgromadzeniami. Przesądził o tym art. 5 ust. 1 Prawa o zgromadzeniach z 1990 r., stwierdzając, że postępowanie w sprawach dotyczących zgromadzeń należy do zadań zleconych organów gminy. W ten sposób ustawodawca zdecydował o realizacji zasady decentralizacji w tym obszarze działalności administracji publicznej. Konstytucja RP zawiera zarówno gwarancje wolności zgromadzeń (w art. 57, który stanowi, że każdemu zapewnia się wolność organizowania pokojo-

Łukasz Kamiński - doktor nauk prawnych, Zakład Prawa Samorządu Terytorialnego Katedra Prawa Administracyjnego i Nauki Administracji, Uniwersytet Łódzki.

${ }^{1}$ Dz.U. z 2013 r. poz. 397 ze zm. - dalej jako: Prawo o zgromadzeniach z 1990 r. 
wych zgromadzeń i uczestniczenia w nich), jak i formułuje zasadę decentralizacji. Zgodnie bowiem z art. 15 ust. 1 Konstytucji RP ustrój terytorialny Rzeczypospolitej Polskiej zapewnia decentralizację władzy publicznej. Zasada decentralizacji ma więc charakter fundamentalnej zasady ustrojowej. W świetle art. 16 ust. 1 Konstytucji RP ogół mieszkańców jednostek zasadniczego podziału terytorialnego stanowi z mocy prawa wspólnotę samorządową. Stosownie do ust. 2 tego przepisu samorządowi terytorialnemu przysługiwać powinna istotna część zadań publicznych, które samorząd ten wykonuje we własnym imieniu i na własną odpowiedzialność. Konstytucja RP nie przesądza jednak, które zadania publiczne powinny być w gestii samorządu terytorialnego, co pozostawia ustawodawcy daleko idącą swobodę w tej mierze. W szczególności nie można z Konstytucji RP wyprowadzić wniosku co do tego, czy nadzór nad zgromadzeniami powinien być realizowany przez zdecentralizowaną administrację samorządową, czy też przez - działającą w układzie scentralizowanym - administrację rządową (np. przez Policję ${ }^{2}$ ). Poruczenie nadzoru nad zgromadzeniami zdecentralizowanym organom gminy pozostaje więc decyzją ustawodawcy i jest tylko jednym z konstytucyjnie dopuszczalnych modeli nadzoru administracyjnoprawnego nad zgromadzeniami.

Już w 1990 r. prowadzenie postępowań w sprawach zgromadzeń ustawodawca zaliczył do zadań z zakresu administracji rządowej zleconych (poruczonych) gminie. Do zadań zleconych odnosi się art. 166 ust. 2 Konstytucji RP, w myśl którego, jeżeli wynika to z uzasadnionych potrzeb państwa, ustawa może zlecić jednostkom samorządu terytorialnego wykonywanie innych zadań publicznych niż zadania własne (o których mowa w ust. 1 tego przepisu), przy czym ustawa określa tryb przekazywania i sposób wykonywania zadań zleconych. W literaturze przedmiotu ${ }^{3}$ zwraca się uwagę, że ustawowe zlecanie

${ }^{2}$ W kwestii postulatu przekazania Policji zadań dotyczących reglamentacji wolności zgromadzeń zob. B. Kołaczkowski, Kompetencje organu gminy w sprawach zgromadzeń. Uwagi krytyczne w kontekście wejścia w życie nowego Prawa o zgromadzeniach [w:] W służbie dobra wspólnego - ludzie, postawy i kompetencje w administracji publicznej, red. B. Jaworska-Dębska, A. Dobaczewska, Warszawa 2016, s. 313-314.

3 S. Fundowicz, Decentralizacja administracji publicznej w Polsce, Lublin 2005, s. 120 . 
zadań jednostkom samorządu terytorialnego powinno być w związku z tym poprzedzone określeniem potrzeb państwa uzasadniających zlecenie zadań. Z drugiej strony w doktrynie ${ }^{4}$ można też spotkać się z poglądami, że kwalifikowanie danego zadania publicznego pozostającego w gestii samorządu terytorialnego jako własnego bądź zleconego zależy w dużym stopniu od uznania ustawodawcy.

Urzeczywistnienie zasady decentralizacji w administracyjnoprawnym nadzorze nad zgromadzeniami nie było zresztą nigdy całkowite, a to z uwagi na trzy okoliczności. Przede wszystkim trzeba zauważyć, że stosownie do przepisów Prawa o zgromadzeniach z 1990 r. to wojewoda był organem odwoławczym w sprawach decyzji o zakazie zgromadzenia publicznego i decyzji o rozwiązaniu zgromadzenia. Po drugie, przez długi czas obowiązywał wymóg uzyskania zezwolenia na zgromadzenie na drodze publicznej. Obowiązek ten wynikał pierwotnie $z$ art. 53 ust. 1 ustawy z 1.02.1983 r. - Prawo o ruchu drogowym ${ }^{5}$, a następnie (po wejściu w życie nowej regulacji ruchu drogowego) z art. 65 ustawy z 20.06.1997 r. - Prawo o ruchu drogowym ${ }^{6}$. W okresie obowiązywania Prawa o zgromadzeniach z 1990 r. właściwość organów w sprawach wydawania zezwoleń na organizowanie zgromadzeń na drogach publicznych ulegała zmianie, jednakże w wielu wypadkach właściwe były tu organy administracji rządowej. Ostatecznie art. 65 Prawa o ruchu drogowym z 1997 r. w części obejmującej wyraz „zgromadzenia” został uznany za niezgodny z art. 57 Konstytucji RP przez Trybunał Konstytucyjny w wyroku z 18.01.2006 r. ${ }^{7}$ Wprawdzie powodem stwierdzenia niekonstytucyjności tego przepisu we wskazanym zakresie nie były kwestie ustrojowe, lecz materialnoprawne (uzyskanie zezwolenia uzależnione zostało od spełnienia licznych a przy tym uciążliwych dla organizatora - wymogów), to jednak skutkiem tego orzeczenia było umocnienie zasady decentralizacji w ob-

${ }^{4}$ L. Habuda, Decentralizacja vs centralizacja administracji $w$ strukturze zasadniczego podziału kraju, Toruń 2009, s. 249.

${ }_{5}$ Dz.U. z 1992 r. poz. 41 ze zm.

6 Dz.U. z 2018 r. poz. 1990 ze zm.

7 Wyrok TK z 18.01.2006 r., K 21/05, OTK-A 2006/1, poz. 4; zob. także B. Naleziński, Glosa do wyroku Trybunału Konstytucyjnego z 18.01.2006 r. (sygn. akt K 21/05), „Przegląd Sejmowy” 2006/3, s. 123-125. 
szarze nadzoru nad zgromadzeniami. Trzecią przyczyną, dla której realizacja zasady decentralizacji w nadzorze nad zgromadzeniami nie była całkowita, jest to, że istotną, praktyczną rolę w tym obszarze odgrywa Policja. Trudno zresztą, żeby było inaczej, skoro gmina nie dysponuje odpowiednimi siłami i środkami dla podejmowania interwencji na zgromadzeniu, w razie gdyby okazało się to konieczne. Wprawdzie ustawodawca zaliczył współdziałanie z organizatorami i innymi służbami w ochronie porządku podczas zgromadzeń do zadań straży gminnych (art. 11 ust. 1 pkt 6 ustawy z 29.08.1997 r. o strażach gminnych ${ }^{8}$ ), ale straże gminne nie funkcjonują we wszystkich gminach. Zresztą nawet tam, gdzie straże gminne zostały utworzone, trudno oczekiwać, by dysponowały wystarczającymi zasobami, aby podejmować interwencje na zgromadzeniach. Zasadniczy ciężar zapewnienia bezpieczeństwa i porządku publicznego na zgromadzeniu spada więc na funkcjonariuszy Policji. Uchwalając w 1990 r. Prawo o zgromadzeniach, ustawodawca zdawał się jednak tego faktu nie dostrzegać, na co zwracano uwagę w piśmiennictwie ${ }^{9}$ dotyczącym tej ustawy. Zasadniczo sytuacja ta nie uległa zmianie do dnia dzisiejszego, mimo wprowadzenia pewnych nowych rozwiązań (dotyczących zgromadzeń spontanicznych). Nadal zasadniczą podstawą do podejmowania czynności przez funkcjonariuszy Policji na zgromadzeniu pozostają ogólne przepisy ustawy z 6.04.1990 r. o Policji ${ }^{10}$. Na podstawie tej ustawy funkcjonariusze Policji podejmują działania skierowane wobec poszczególnych członków zgromadzenia, a nie adresowane do zgromadzenia in toto. Trudno jednak nie zauważyć, że działania podejmowane względem poszczególnych uczestników zgrupowania (np. legitymowanie, zatrzymanie) wywierają wpływ na to zgrupowanie jako całość (zwłaszcza gdy są podejmowane na szeroką skalę) $)^{11}$.

${ }^{8}$ Dz.U. z 2018 r. poz. 928 ze zm.

9 B. Kołaczkowski, Kształtowanie się regulacji prawnych zgromadzeń w Polsce oraz w wybranych krajach o anglosaskiej tradycji prawnej, Warszawa 2014, s. 127-128.

10 Dz.U. z 2017 r. poz. 2067 ze zm.

${ }^{11}$ Szerzej o uprawnieniach funkcjonariuszy Policji względem zgromadzeń i ich uczestników pisałem w opracowaniu Ł. Kamiński, Funkcjonariusze Policji na zgromadzeniu. Stużba dobru wspólnemu a ochrona wolności zgromadzeń [w:] W służbie..., red. B. Jaworska-Dębska, A. Dobaczewska, s. 287-300. 
Wejście w życie nowej administracyjnoprawnej regulacji zgromadzania się, tj. ustawy z 24.07.2015 r. - Prawo o zgromadzeniach ${ }^{12}$, oraz jej nowelizacja ustawą z 13.12.2016 r. o zmianie ustawy - Prawo o zgromadzeniach ${ }^{13}$ oznaczały zmianę modelu nadzoru nad zgromadzeniami. Zmiana ta nie ma co prawda charakteru zasadniczego, jako że podstawowe założenia Prawa o zgromadzeniach z 1990 r. zostały przeniesione do nowej ustawy, w tym w dalszym ciągu nadzór nad zgromadzeniami należy do organów gminy. Zgodnie bowiem $\mathrm{z}$ art. 6 Prawa o zgromadzeniach zadania w zakresie postępowania w sprawach dotyczących zgromadzeń należą do zadań zleconych gminy, na obszarze której jest organizowane zgromadzenie. W pewnym sensie decentralizacja uległa tu nawet wzmocnieniu, skoro odwołanie od decyzji w sprawie zakazu zgromadzenia oraz decyzji o rozwiązaniu zgromadzenia jest rozpatrywane przez sąd powszechny, a nie przez organ administracji rządowej (co wynika - odpowiednio - z art. 16 ust. 1 oraz art. 20 ust. 4 pr. zgr.). Trudno jednak nie zauważyć dwóch tendencji zmian, jakie zarysowały się w Prawie o zgromadzeniach, a następnie zostały pogłębione w nowelizacji. Z jednej strony jest to tendencja do przedmiotowej dyferencjacji zgromadzeń, a z drugiej strony wzrasta znaczenie scentralizowanej administracji rządowej w nadzorze nad zgromadzeniami. Oba te kierunki zmian są ze sobą powiązane.

W obecnie obowiązującym Prawie o zgromadzeniach można mówić o wyodrębnieniu trzech szczególnych kategorii zgromadzeń (obok zgromadzeń organizowanych na zasadach ogólnych, uregulowanych w rozdziale 2 Prawa o zgromadzeniach). Te szczególne kategorie zgromadzeń obejmują: zgromadzenia organizowane w trybie uproszczonym (rozdział 3 Prawa o zgromadzeniach), zgromadzenia spontaniczne (rozdział 4) oraz - wprowadzone przez nowelizację z 2016 r. - zgromadzenia organizowane cyklicznie (rozdział 3a). Wszystkie te trzy kategorie zgromadzeń wyróżniają się swoistymi odrębnościami proceduralnymi.

Najdalej idące różnice dotyczą zgromadzeń spontanicznych. Jest to też jedyna kategoria zgromadzeń, która doczekała się definicji legalnej.

12 Dz.U. z 2018 r. poz. 408 ze zm. - dalej jako: pr. zgr.

13 Dz.U. poz. 579. 
Stosownie do art. 3 ust. 2 pr. zgr. zgromadzeniem spontanicznym jest zgromadzenie, które odbywa się w związku z zaistniałym nagłym i niemożliwym do wcześniejszego przewidzenia wydarzeniem związanym ze sferą publiczną, którego odbycie w innym terminie byłoby niecelowe lub mało istotne z punktu widzenia debaty publicznej. Generalnie rzecz biorąc, definicja ta stanowi przeniesienie na grunt ustawowy artykułowanej w doktrynie ${ }^{14}$ idei zgromadzeń spontanicznych. Zgromadzenia spontaniczne - jako jedna $\mathrm{z}$ form realizacji wolności zgromadzeń - zostały afirmowane w wyroku Trybunału Konstytucyjnego z 18.09.2014 r. ${ }^{15}$ Z uzasadnienia powołanego orzeczenia wynika, że Trybunał Konstytucyjny uznał możliwość organizacji zgromadzeń spontanicznych (tj. zgromadzeń będących natychmiastową reakcją opinii publicznej na bieżące wydarzenia) za składnik istoty wolności zgromadzeń. Taka ocena przyczyniła się do uznania za niekonstytucyjny terminu zgłoszenia zgromadzenia przewidzianego w ówcześnie obowiązującym Prawie o zgromadzeniach z 1990 r.

Według aktualnej regulacji zgromadzenia spontaniczne nie wymagają notyfikowania jakimkolwiek organom władzy publicznej. Nie jest też możliwe wydanie prewencyjnego zakazu takiego zgromadzenia. Nadzór nad zgromadzeniami spontanicznymi jest więc ograniczony do nadzoru bieżącego, przy czym ustawodawca przewidział, że nadzór ten sprawuje Policja. I tak, w świetle art. 28 ust. 1 pr. zgr., zgromadzenie spontaniczne może być rozwiązane przez funkcjonariusza kierującego działaniami Policji, jeżeli: jego przebieg zagraża życiu lub zdrowiu ludzi albo mieniu w znacznych rozmiarach; jego przebieg powoduje poważne zagrożenie bezpieczeństwa lub porządku publicznego; powoduje istotne zagrożenie bezpieczeństwa lub porządku ruchu drogowego na drogach publicznych; jego przebieg narusza przepisy Prawa o zgromadzeniach albo przepisy karne; zakłóca przebieg zgromadzenia organizowanego na zasadach ogólnych lub w trybie uproszczonym, a także zgromadzenia organizowanego cyklicznie.

${ }_{14}$ Zob. A. Bodnar, M. Ziółkowski, Zgromadzenia spontaniczne, PiP 2008/5; H. Zadrożniak, Zgromadzenia publiczne jako forma udziału obywateli w życiu społecznym, ST 2009/5, s. 65-67.

${ }^{15}$ Wyrok TK z 18.09.2014 r., K 44/12, OTK-A 2014/8, poz. 92. 
W odniesieniu do zgromadzeń spontanicznych ustawodawca zdecydował się zatem na model nadzoru sprawowanego wyłącznie przez administrację rządową.

Natomiast w odniesieniu do dwóch pozostałych kategorii zgromadzeń, tj. zgromadzeń organizowanych $w$ trybie uproszczonym oraz zgromadzeń organizowanych cyklicznie, mamy do czynienia z modelem mieszanym, gdzie zasadnicza część uprawnień nadzorczych należy do organów zdecentralizowanych, natomiast pewne zadania wykonują też organy administracji rządowej.

Gdy chodzi o zgromadzenia organizowane w trybie uproszczonym (na podstawie rozdziału 3 Prawa o zgromadzeniach), to zasadniczo nadzór nad takimi zgromadzeniami należy w całości do gmin, chyba że w danej gminie nie powołano gminnego (miejskiego) centrum zarządzania kryzysowego. O ile bowiem w odniesieniu do zgromadzeń organizowanych na zasadach ogólnych ustawodawca przewidział wymóg zawiadomienia organu gminy (art. 7 ust. 1 pr. zgr.), o tyle w przypadku zgromadzeń organizowanych w oparciu o procedurę uproszczoną znajdzie zastosowanie art. 22 ust. 1 pr. zgr. Przepis ten przewiduje, że organizator takiego zgromadzenia zawiadamia o zamiarze zorganizowania zgromadzenia właściwe gminne (miejskie) centrum zarządzania kryzysowego, a w przypadku gdy w danej gminie nie zostało ono utworzone, ma obowiązek zawiadomić wojewódzkie centrum zarządzania kryzysowego. Zgodnie bowiem z art. 20 ust. 2 ustawy z 26.04.2007 r. o zarządzaniu kryzysowym ${ }^{16}$ utworzenie gminnego (miejskiego) centrum zarządzania kryzysowego jest fakultatywne. Stąd też w gminach, w których organ wykonawczy takiego centrum nie utworzył, zgłoszenia zgromadzeń organizowanych w oparciu o przepisy rozdziału 3 Prawa o zgromadzeniach przyjmuje wojewódzkie centrum zarządzania kryzysowego. Tworzenie takich centrów jest bowiem obligatoryjne, stosownie do art. 16 ust. 1 ustawy o zarządzaniu kryzysowym. A zatem jeżeli $\mathrm{w}$ danej gminie nie utworzono gminnego (miejskiego) centrum zarządzania kryzysowego, to przyjmowanie zawiadomień o zgromadzeniach organizowanych w trybie uproszczonym będzie należeć do komórki or-

${ }^{16}$ Dz.U. z 2018 r. poz. 1401 ze zm. - dalej jako: ustawa o zarządzaniu kryzysowym. 
ganizacyjnej usytuowanej w strukturze scentralizowanej administracji rządowej. Jednakże już w sprawach nadzoru bieżącego nad takim zgromadzeniem właściwy będzie w każdym wypadku organ gminy, gdyż to organ gminy będzie miał prawo (a niekiedy nawet obowiązek) delegowania przedstawiciela na zgromadzenie (co wynika z art. $17 \mathrm{w} z w$. $\mathrm{z}$ art. 26 pr. zgr.), a przedstawiciel ten będzie uprawniony - w określonych sytuacjach - do rozwiązania zgromadzenia (art. 25 ust. 1).

Rola wojewódzkiego centrum zarządzania kryzysowego nie kończy się jednak na samym tylko przyjmowaniu zawiadomień o zgromadzeniach organizowanych w trybie uproszczonym. Artykuł 26 pr. zgr. przewiduje bowiem, że do tych zgromadzeń stosuje się odpowiednio niektóre przepisy dotyczące zgromadzeń organizowanych na zasadach ogólnych, w tym - art. 12 i 13 omawianej ustawy. Przepisy te przewidują szczególną procedurę rozstrzygania kolizji między wolnością zgromadzeń przysługującą różnym podmiotom w sytuacji, gdy zgłoszono więcej niż jedno zgromadzenie mające się odbyć (choćby częściowo) w tym samym miejscu i czasie. Jak się wydaje, odpowiednie stosowanie tych przepisów do zgromadzeń organizowanych w trybie uproszczonym będzie oznaczać ich stosowanie z taką modyfikacją, że to nie organ gminy, lecz właściwe do przyjęcia zgłoszenia centrum zarządzania kryzysowego będzie uprawnione do przeprowadzenia czynności w ramach procedury określonej w art. 12 i 13 pr. zgr. A zatem w sytuacji, gdy wojewódzkie centrum zarządzania kryzysowego było właściwe do przyjęcia zawiadomienia, będzie ono również właściwe do przeprowadzenia postępowania na podstawie art. 12 i 13 pr. zgr., o ile zachodzą ku temu przesłanki. W wyniku tego postępowania - odmiennie niż w przypadku zgromadzeń organizowanych na zasadach ogólnych - nie może być jednak wydany zakaz zgromadzenia, a zatem wojewódzkie centrum zarządzania kryzysowego (tak samo zresztą, jak i miejskie czy gminne centrum zarządzania kryzysowego) nie będzie wydawać w tej sprawie żadnych aktów administracyjnych, a jedynie podejmować czynności materialno-techniczne.

Nowelizacja z 2016 r. wprowadziła do Prawa o zgromadzeniach nowy typ zgromadzeń, tj. zgromadzenia organizowane cyklicznie, uregulowane w rozdziale 3a tej ustawy. W myśl art. 26a ust. 1 pr. zgr., jeżeli zgromadzenia są organizowane przez tego samego organizatora 
w tym samym miejscu lub na tej samej trasie co najmniej cztery razy w roku według opracowanego terminarza lub co najmniej raz w roku w dniach świąt państwowych i narodowych, a tego rodzaju wydarzenia odbywały się w ciągu ostatnich 3 lat, chociażby nie w formie zgromadzeń i miały na celu w szczególności uczczenie doniosłych i istotnych dla historii Rzeczypospolitej Polskiej wydarzeń, organizator może zwrócić się z wnioskiem do wojewody o wyrażenie zgody na cykliczne organizowanie tych zgromadzeń.

Zgoda na cykliczne organizowanie zgromadzeń stanowi szczególnego rodzaju akt administracyjny. Nie jest to typowe pozwolenie administracyjne, gdyż istotą pozwolenia administracyjnego jest uchylenie - $\mathrm{w}$ indywidualnej i konkretnej sprawie - abstrakcyjnego i generalnego zakazu podejmowania oraz prowadzenia określonej działalności ${ }^{17}$. Istotą decyzji o wyrażeniu zgody na cykliczne organizowanie zgromadzeń nie jest indywidualne uchylenie żadnego ustawowego zakazu, gdyż żaden generalny zakaz organizowania zgromadzeń (czy to o charakterze cyklicznym, czy też o innym charakterze) nie istnieje. Zakaz zgromadzenia ma zawsze charakter indywidualnego aktu administracyjnego, który organ gminy ma obowiązek wydać, gdy zaistnieją ustawowe przesłanki. Zgoda na cykliczne organizowanie zgromadzeń nie znosi zresztą zakazu zgromadzenia wydanego przez organ gminy ani nie wyłącza możliwości wydania takiego zakazu. Istotą tej decyzji jest przyznanie pewnym, planowanym zgromadzeniom szczególnego przymiotu normatywnego. Skutkiem wydania zgody na cykliczne organizowanie zgromadzeń są pewne odrębności proceduralne (zgromadzenie nie wymaga zgłoszenia organowi gminy), a także przyznanie takiemu zgromadzeniu pierwszeństwa, w razie gdy zgłoszono zamiar zorganizowania innego zgromadzenia bądź też zgromadzeń w tym samym miejscu i czasie.

Analiza treści art. 26b ust. 1 prowadzi do wniosku, że decyzja o wyrażeniu zgody na cykliczne organizowanie zgromadzeń ma charakter aktu administracyjnego uznaniowego. W świetle tego przepisu wo-

${ }^{17}$ Szerzej na temat klasycznej koncepcji istoty pozwolenia administracyjnego zob. D. Kijowski, Pozwolenia $w$ administracji publicznej. Studium z teorii prawa administracyjnego, Białystok 2000, s. 41-42. 
jewoda wydaje decyzję w przedmiocie zgody na cykliczne organizowanie zgromadzeń nie później niż na 5 dni przed planowanym terminem pierwszego z cyklu zgromadzeń, biorąc w szczególności pod uwagę okoliczność wcześniejszego organizowania zgromadzeń przez wnioskodawcę oraz cel cyklicznego organizowania zgromadzeń. Cel ten tudzież jego uzasadnienie powinny być - stosownie do art. 26a ust. 2 - podane we wniosku o wydanie tej decyzji. Zwrotu, że wojewoda „wydaje” decyzję, nie należy przy tym interpretować w ten sposób, że ma obowiązek to zrobić. W art. 26b ust. 1 ab initio ustawodawca wskazuje jedynie materialnoprawny, zawity termin do wydania decyzji w przedmiocie wyrażenia zgody na cykliczne organizowanie zgromadzeń. Artykuł 26b ust. 1 in fine wskazuje przesłanki, jakimi wojewoda ma się „w szczególności” kierować, co oznacza, że decydując o wydaniu omawianej decyzji, może brać pod uwagę również inne, niewymienione w tym przepisie okoliczności sprawy.

Ustawodawca zadecydował, że o nadaniu planowanym zgromadzeniom tego szczególnego przymiotu normatywnego decydować będzie organ administracji rządowej, jakim jest wojewoda. Przy organie wykonawczym gminy pozostają jednak kompetencje do: wydania zakazu zgromadzenia (art. 14 w zw. z art. 26e pr. zgr.), delegowania na to zgromadzenie swojego przedstawiciela (art. 17 ust. $1 \mathrm{w}$ zw. art. 26e pr. zgr.) oraz rozwiązania zgromadzenia (art. 20 ust. 1 w zw. z art. 26e pr. zgr.). Aby wójt (burmistrz, prezydent miasta) mógł realnie sprawować nadzór nad zgromadzeniem organizowanym cyklicznie, konieczne jest - wobec braku wymogu zawiadomienia o tym zgromadzeniu - przekazanie stosownej informacji przez wojewodę temu organowi. Tego rodzaju obowiązek informacyjny określa art. 26b ust. 2 in fine pr. zgr., zgodnie z którym wojewoda informuje o wydaniu omawianej decyzji organ gminy, na terenie której ma się odbyć zgromadzenie cykliczne. A zatem w przypadku zgromadzeń organizowanych cyklicznie mamy do czynienia z mieszanym, rządowo-samorządowym modelem ich nadzoru.

Istota zgromadzeń cyklicznych sprowadza się do przyznania im pierwszeństwa przed zgromadzeniami organizowanymi na zasadach ogólnych. Reguła ta została wprost wyrażona w art. 12 ust. 1 zd. 3 pr. zgr., który głosi, że zgromadzeniom organizowanym cyklicznie przysłu- 
guje pierwszeństwo wyboru miejsca i czasu zorganizowania zgromadzenia. Nadto zgodnie z art. 14 pkt 3 powołanej ustawy organ gminy wydaje decyzję o zakazie zgromadzenia, jeżeli ma się ono odbyć w miejscu i czasie, w których odbywają się zgromadzenia organizowane cyklicznie. Uzupełnieniem tej regulacji jest przepis art. 26b ust. 3, który stanowi, że jeżeli wojewoda wydał zgodę na odbycie zgromadzenia cyklicznego w miejscu i czasie, w których miało się odbyć inne zgromadzenie, organ gminy, w ciągu 24 godzin od otrzymania informacji, o której mowa w ust. 2, wydaje decyzję o zakazie tego zgromadzenia. Dla zabezpieczenia wykonania tego obowiązku przez organ wykonawczy gminy ustawodawca wyposażył wojewodę w szczególny środek nadzoru. Zgodnie bowiem $\mathrm{z}$ art. $26 \mathrm{~b}$ ust. $4 \mathrm{w}$ przypadku niewykonania przez organ gminy obowiązku, o którym mowa w art. 26b ust. 3, wojewoda wydaje niezwłocznie zarządzenie zastępcze o zakazie zgromadzenia. Wątpliwości może natomiast budzić to, czy wydanie zarządzenia zastępczego jest możliwe w razie uchybienia przez organ wykonawczy gminy obowiązkowi wydania zakazu zgromadzenia wynikającemu $\mathrm{z}$ art. 14 pkt 3. Ustawa takiej możliwości expressis verbis nie przewiduje. Niemniej jednak przyjęcie, że wojewoda może (a właściwie ma obowiązek) wydać zarządzenie zastępcze tylko wtedy, gdy organ gminy uchybił obowiązkowi wydania zakazu w przypadku zgromadzeń zgłoszonych przed wydaniem decyzji o wyrażeniu zgody na cykliczne organizowanie konkurencyjnego zgromadzenia, ale już nie po wydaniu takiej decyzji, prowadziłoby w gruncie rzeczy ad absurdum. Stąd też zasadne wydaje się przyjęcie - w oparciu o wykładnię funkcjonalną - że wydanie zarządzenia zastępczego wchodzi w rachubę w każdym przypadku uchybienia przez organ gminy obowiązkowi wydania zakazu zgromadzenia, które koliduje ze zgromadzeniem organizowanym cyklicznie.

Nie jest również jasny charakter zarządzenia zastępczego wojewody, wydawanego w oparciu o art. 26 b ust. 4 pr. zgr., a co za tym idzie, wątpliwości budzi także kwestia przysługującej w tym wypadku drogi sądowej. Między innymi do tej materii odniósł się Trybunał Konstytucyjny w wyroku z 16.03.2017 r. ${ }^{18}$, dotyczącym konstytucyjności instytucji zgromadzeń organizowanych cyklicznie. W uzasadnieniu

${ }_{18}$ Wyrok TK z 16.03.2017 r., Kp 1/17, OTK-A 2017, poz. 28. 
tego orzeczenia Trybunał stwierdził, że: „Zarządzenie zastępcze wojewody o zakazie zgromadzenia jest [...] decyzją organu administracji publicznej, która jest aktem administracyjnym”. W dalszej części uzasadnienia Trybunał przyjął, że prokonstytucyjna wykładnia Prawa o zgromadzeniach prowadzi do wniosku, że możliwe jest zaskarżenie do sądu zarządzenia zastępczego przez organizatora zgromadzenia. Trybunał nie wskazał jednak, czy właściwy byłby w takim wypadku sąd administracyjny czy sąd powszechny (który byłby właściwy, gdyby to organ gminy wydał zakaz zgromadzenia), uznając oba kierunki wykładni za spełniające wymogi konstytucyjne.

Zarządzenie zastępcze, będąc środkiem nadzoru nad działalnością gminy, ma jednak również wszelkie cechy aktu administracyjnego skierowanego do organizatora zakazanego zgromadzenia. Dyskusyjne jest, czy można uznać, że ma formę procesową decyzji administracyjnej. Mogłaby za taką wykładnią przemawiać formułowana w piśmiennictwie ${ }^{19}$ zasada domniemania formy decyzji administracyjnej. W każdym razie w przypadku wydania omawianego zarządzenia zastępczego organizator zgromadzenia, które zostało w ten sposób zakazane, może zaskarżyć to zarządzenie do sądu. Właściwy będzie tutaj sąd powszechny. Wniosek taki można sformułować w oparciu o stosowany per analogiam art. 16 ust. 1 pr. zgr., zgodnie z którym odwołanie od decyzji o zakazie zgromadzenia wnosi się bezpośrednio do sądu okręgowego. A zatem w takim samym trybie, choć ustawa wprost tego nie przewiduje, zaskarżeniu podlegać będzie zarządzenie zastępcze wojewody o zakazie zgromadzenia. Teza o kognicji sądu okręgowego znajduje swoje potwierdzenie w orzecznictwie sądowym. Na możliwość stosowania przez analogię art. 16 pr. zgr. do zarządzenia zastępczego wojewody zakazującego zgromadzenia wskazał Sąd Apelacyjny w Warszawie w postanowieniu z 2.06.2017 r. ${ }^{20}$ Jednocześnie Sąd ten przyjął, że jedynie organizator zgromadzenia jest legitymowany do wniesienia odwołania od zarządzenia zastępczego

19 B. Adamiak, Zagadnienie domniemania formy decyzji administracyjnej [w:] Podmioty administracji publicznej i prawne formy ich działania. Studia i materiały $z$ Konferencji Naukowej Poświęconej Jubileuszowi 80-tych urodzin Profesora Eugeniusza Ochendowskiego, Toruń 2005, s. 17-20.

${ }^{20}$ Postanowienie SA w Warszawie z 2.06.2017 r., I ACz 889/17, LEX nr 2300204. 
wojewody, natomiast wójt (burmistrz, prezydent miasta) nie może ani wnieść odwołania, ani uczestniczyć w postępowaniu w sprawie odwołania od zarządzenia zastępczego zakazującego zgromadzenia.

W powołanym wyżej orzeczeniu Sąd Apelacyjny trafnie przyjął, że wojewoda nie może wydać zarządzenia zastępczego w przedmiocie zakazu zgromadzenia organizowanego w trybie uproszczonym, tj. w oparciu o przepisy rozdziału 3 Prawa o zgromadzeniach, nawet gdyby takowe zgromadzenie miało kolidować ze zgromadzeniem cyklicznym. W odniesieniu do zgromadzeń organizowanych w trybie uproszczonym brak jest bowiem podstawy prawnej do ich zakazania przez organ gminy czy zresztą jakikolwiek inny organ władzy publicznej. W związku z tym nie może zaistnieć w tym przypadku bezczynność organu gminy będąca przesłanką wydania zarządzenia zastępczego.

Powyższe rozważania pozwalają na sformułowanie kilku wniosków. Przede wszystkim trzeba odnotować, że ustawodawca przyjął zdecentralizowany model administracyjnoprawnego nadzoru nad zgromadzeniami, gdyż - co do zasady - zadania dotyczące tego nadzoru pozostają w gestii organów gmin, a więc organów działających w układzie zdecentralizowanym. Istnieje jednak kilka szczególnych kategorii zgromadzeń, w odniesieniu do których (obok istotnych odrębności materialnoprawnych) pojawia się, z różnym zresztą natężeniem, tendencja do centralizacji. Wyraża się ona w powierzeniu przez ustawodawcę pewnych zadań związanych z nadzorem nad tymi zgromadzeniami podmiotom administrującym działającym w ramach scentralizowanej administracji rządowej. Najsilniej jest to widoczne w odniesieniu do zgromadzeń spontanicznych, gdyż nadzór został w całości powierzony Policji. Z modelem mieszanym mamy natomiast do czynienia w odniesieniu do zgromadzeń organizowanych cyklicznie, gdzie pewne zadania zostały przekazane wojewodzie i co za tym idzie - są wykonywane na zasadzie centralizacji. Wojewoda zyskał przy tym szczególny środek nadzoru, jakim jest zarządzenie zastępcze w przedmiocie zakazu zgromadzenia, które kolidowałoby ze zgromadzeniem organizowanym cyklicznie. Zastosowanie tego środka jest możliwe w razie bezczynności organu gminy polegającej na niewydaniu zakazu takiego zgromadzenia. Z drugiej jednak strony 
istotna część zadań związanych ze zgromadzeniami cyklicznymi pozostaje przy gminie. Stosunkowo najsłabsze akcenty zmian w kierunku centralizacji pojawiają się, gdy chodzi o zgromadzenia organizowane w trybie uproszczonym. W odniesieniu do tych zgromadzeń pewne czynności o charakterze materialno-technicznym (np. przyjmowanie zawiadomień o zgromadzeniach) są wykonywane przez wojewódzkie centra zarządzania kryzysowego, gdy brak jest w danej gminie gminnego (miejskiego) centrum zarządzania kryzysowego.

\section{Bibliografia:}

Adamiak B., Zagadnienie domniemania formy decyzji administracyjnej [w:] Podmioty administracji publicznej i prawne formy ich działania. Studia i materiały z Konferencji Naukowej Poświęconej Jubileuszowi 80-tych urodzin Profesora Eugeniusza Ochendowskiego, Torun 2005

Bodnar A., Ziółkowski M., Zgromadzenia spontaniczne, PiP 2008/5

Fundowicz S., Decentralizacja administracji publicznej w Polsce, Lublin 2005

Habuda L., Decentralizacja vs centralizacja administracji w strukturze zasadniczego podziału kraju, Toruń 2009

Kamiński Ł., Funkcjonariusze Policji na zgromadzeniu. Służba dobru wspólnemu a ochrona wolności zgromadzeń [w:] W stużbie dobra wspólnego - ludzie, postawy $i$ kompetencje $w$ administracji publicznej, red. B. Jaworska-Dębska, A. Dobaczewska, Warszawa 2016

Kijowski D., Pozwolenia w administracji publicznej. Studium z teorii prawa administracyjnego, Białystok 2000

Kołaczkowski B., Kompetencje organu gminy w sprawach zgromadzeń. Uwagi krytyczne w kontekście wejścia w życie nowego Prawa o zgromadzeniach [w:] W stużbie dobra wspólnego - ludzie, postawy i kompetencje w administracji publicznej, red. B. Jaworska-Dębska, A. Dobaczewska, Warszawa 2016

Kołaczkowski B., Kształtowanie się regulacji prawnych zgromadzeń w Polsce oraz $w$ wybranych krajach o anglosaskiej tradycji prawnej, Warszawa 2014

Naleziński B., Glosa do wyroku Trybunału Konstytucyjnego z 18.01.2006 r. (sygn. akt K 21/05), „Przegląd Sejmowy” 2006/3

Zadrożniak H., Zgromadzenia publiczne jako forma udziału obywateli w życiu społecznym, ST 2009/5 